$300-340^{\circ}$

$106.5 \mathrm{~g}$

結晶

$2.5 \mathrm{~g}$

106. $\mathrm{g}$ の油分は再び蒸溜コルベンにもどして熱す

$300^{\circ}$ 上上 $74.0 \mathrm{~g}$

結晶 $5.8 \mathrm{~g}$

この油分も再びもどして

$300^{\circ}$ 以上 $67.0 \mathrm{~g}$

結晶 $2.2 \mathrm{~g}$

かくして得たる結晶の合計 $10.5 \mathrm{~g}$ 前記コロフォニウムより得たる結晶の如く 石汕エーテル酒精其他種々なる溶娈在以て所理して Anthracen 及 Phenanthren を 得たりナントラツェンは前と同樣に證明せり・フェナントレンは Smp 100 にして

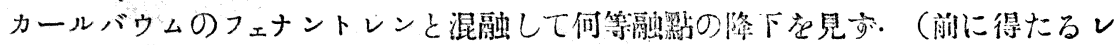
ーテンと混融するに ca $80^{\circ}$ となる).

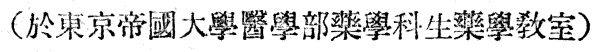

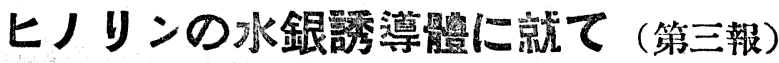

染學士鵜 飼真二

T. Ukai : Ueber Quecksilberverbindungen des Chinolins (III)

（I）凡そ化合物が何等かの溶媒に溶け易き性質を具有する事は之を應用する

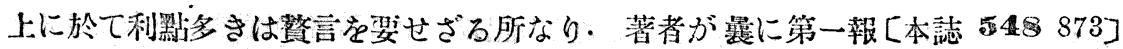
に於て热告したる 8-Chlor-mercuri-chinolin は头自身に於てもべンッォール其他の 有㙨性溶媒に溶解すれ共其程度は僅少に過ぎす。．今之を $\mathrm{R}-\mathrm{Hg}-\mathrm{R}$ 型化合物に變 方る事を得ば页に有機性溶媒に對する溶解度を塯加する事究得べしとの考へより 8-,8'-Mercuri-bischinolin の合成を試みたり.

R-Hg-Halg. 常 R-Hg-R に變するにはは數多の方法あり. 又化合物の種類により てその難易を異にす。例へば $\alpha$-Jodmercurithiophen は自然に放置するも後者に㬍 移する性質われ共 $\beta$ 位に $-\mathrm{HgJ}$ のあるものは比较的安定なり. 又クロール化合 物及びブローム化合物はえに對應するヨード化合物よりも安定なり．故に之等よ 与 $\mathrm{R}-\mathrm{Hg}-\mathrm{R}$ 型化合物蛍導くには先づ不安定なる $(\mathrm{R}-\mathrm{Hg})_{2} \mathrm{~S}$ 若くは $\mathrm{RHg}-\mathrm{S}-\mathrm{SO}_{3} \mathrm{Na}$ 等に誘導して然方後目的を達するを一般とす.

著者は初め 8-Chlormercurichinolin のベンッォール溶液を乾燥硫化水素を通じて 生跱る硫化物在種々の條件に於て熱して 8,8'-Mercuri-bischinolin に達せしめんと 
せしが凡て失敗に歸したりり。

次に物質を震厚なる次亞硫酸曹達溶液にて處理したるに签易く所期の目的を達 し得たり・毁ち約 $50 \%$ の次亞硫酸曹達の過剩の中に 8-Chlormercurichinolin の

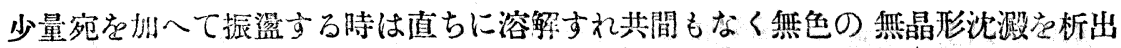

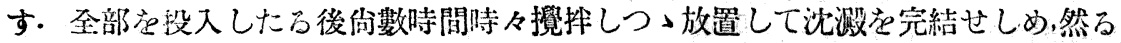
後吸引滤過する時は殆ぞ定量的に 8,8'-Mercuri-bischinolin を得・此場合の反應は 次の如なるべし.

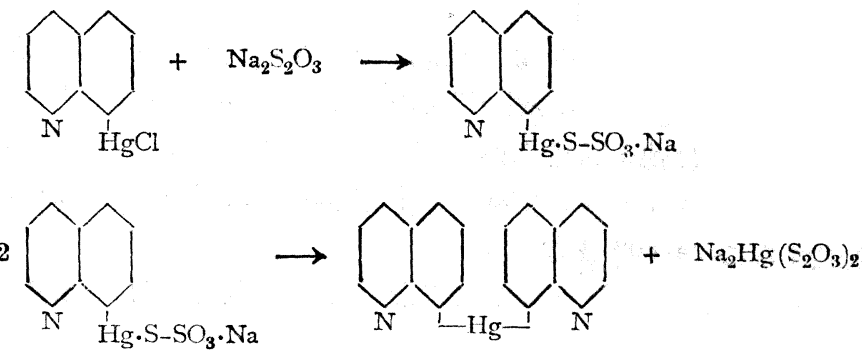

此反應を加熱によりて促進せしめんと試みたれども成績體は灰色より黑色に變 じて失殿したり.

8,8'-Mercuri-bischinolin は己芭べンツォールより結晶せしされれば針狀及は板狀の 結晶として得られ $178^{\circ}-182^{\circ}$ にて分解しつっ踷融す. 水には溶解せす. クロ、 フォルム所にベンツォールには容易く溶解し又オレーフ油にも溶解す。

(II) 熔融呫 $179^{\circ}$ の Chlormercurichinolin の - $\mathrm{HgCl}$ が(8) の值置に結合せる 事は己窟 Bromchinolin に導き合成品と此較して既に證明したる所なれ共 【本誌 వ43, 876]8-Bronchinolin に關しては文獻の記載の中に著者の實驗と一致せざる所

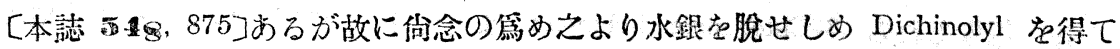
文獻記載の $8,8^{\prime}$-Dichinolyl と比較せんと企てたり.

著者は物質に銅の細末を混じて乾溜㾜試みたるに溜液にはとノリン及び水銀と 共に少量乍ら冷却後固結する物質を得たり. 之をク口ロフォルムより再結晶せし むれば融覧 $205^{\circ}-206^{\circ}$ の無色の結晶となる. 即ち St. von Niementowski が 2,2'Diaminodiphenyl より合成したる 8,8-Dichinolyl に一致す. (B. 38 764) 分析及 び分子量测定の䋨果も及之と矛盾せず。故に融點 $179^{\circ}$ の物質は 8-Chlormercurichinolin に他ならざる事を愈々確め得たり.

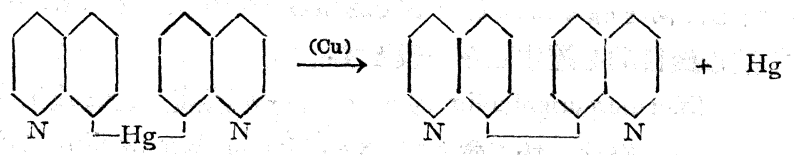




\section{實驗之 部}

(1) 8,8-Mercuribis-chinolin. 次亞硫酸曹達 20g t $60 \mathrm{cc}$ の水に溶解し之に約

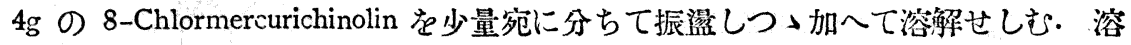
解後間もなく沈澱叴析出し始さるを以て全部を加へ終る頃には相當量の沈澱を析 出す. 份約 3 時間時を摫拌しつ」放置たる後吸引滤過し除濕器中に乾燥す。（稌 りに長く放置する時は硫黃を夾雜する㲊うるが故によろしからすう・ ベンッォール より數包再結晶せしめたるものは明かなる融點を示さざれ共 $178^{\circ}-182^{\circ}$ に於て分 解しつ〉熔融す.

$$
\begin{array}{lllll}
\text { 分 析 } & & & & \\
\text { 物資 } 0.1381 \mathrm{~g} & \mathrm{Hg}_{2} \mathrm{Cl}_{2}: & 0.0708 \mathrm{~g} & \mathrm{Hg} \% & 43.58 \\
\text { 物啠 } 0.1118 \mathrm{~g} & \mathrm{Hg}_{2} \mathrm{Cl}_{2}: & 0,0576 \mathrm{~g} & \mathrm{Hg} \% & 43.77 \\
\left(\mathrm{C}_{9} \mathrm{H}_{6} \mathrm{~N}\right)_{2} \mathrm{Hg} \text { としての理論數 } & & \mathrm{Hg} \% & 43.92
\end{array}
$$

(II) 8,8'-Dichinolyl. 本實驗に使用したる銅は硫酸銅を亞鉛末にて還元したろ 細末狀のものなり・[Lassar-Cohn, Arbeitsmethoden der org. Chemie (1903), S. 330] 粗製 8,8'-Mercuri-bischinolin（融點 $170^{\circ}$ 附近のもの） $10 \mathrm{~g}$ に $5 \mathrm{~g}$ の銓末を混じ 蒸溜コルベンに入れて直火にて乾溜す。始めは水銀と共にヒノリン臭ある液體

\begin{tabular}{|c|c|c|c|c|c|}
\hline \multirow{2}{*}{\multicolumn{2}{|c|}{ 物䆩 $0.1674 \mathrm{~g}$}} & $\mathrm{CO}_{2}:$ & $0.5099 \mathrm{~g}$ & $\mathrm{H}_{2} \mathrm{O}:$ & $0.0848 \mathrm{~g}$ \\
\hline & & $\mathrm{C} \%$ & 83.07 & $\mathrm{H} \%$ & 5.67 \\
\hline \multirow[t]{2}{*}{ 物資 } & \multirow[t]{2}{*}{$0.1505 \mathrm{~g}$} & $\mathrm{CO}_{2}:$ & $0.4599 \mathrm{~g}$ & $\mathrm{H}_{2} \mathrm{O}:$ & $0.0728 \mathrm{~g}$ \\
\hline & & $\mathrm{C} \%$ & 83.34 & $\mathrm{H} \%$ & 5.42 \\
\hline 物貿 & $0.1855 \mathrm{~g}$ & $\mathrm{~N}_{2}$ : & $17.8 \mathrm{sc}\left(762 \mathrm{~mm} 22^{\circ}\right)$ & $\mathrm{N} \%$ & 10.74 \\
\hline \multirow[t]{2}{*}{ 物貿 } & $0.1438 \mathrm{~g}$ & $\mathrm{~N}_{2}$ : & $13.6 \mathrm{cc}\left(762 \mathrm{~mm} 23^{\circ}\right)$ & $\mathrm{N} \%$ & 10.63 \\
\hline & \multicolumn{3}{|c|}{ （但し堂素測定には $50 \%$ 菏性加里え用ひけり） } & & \\
\hline & としての理論數 & $\mathrm{C} \%$ & $\mathrm{H} \% 5.47$ & $\mathrm{~N} \%$ & 10.85 \\
\hline
\end{tabular}
(A)凅出すれ共蒸溜末期に至りて冷却器中にて固化する物質(B)学溜出す。物質 (A)は之を再溜すれば士として沸點 $236^{\circ}-237^{\circ}$ の無色の溜液学得. 郎ちヒノリン の沸點にして分析數又之れに一致す。

物質 (B) は綠褐色を星すれ共獸炭を用ひて之を再結晶すれば無色となる。融點

\begin{tabular}{|c|c|c|}
\hline 物資 $0.0583 \mathrm{~g}$ & $\mathrm{~N}_{2}: 5.8 \mathrm{cc}\left(768 \mathrm{~mm} 23^{\circ}\right)$ & N\% 11.30 \\
\hline $\mathrm{C}_{18} \mathrm{H}_{12} \mathrm{~N}_{2}$ として理論數 & & $\mathrm{N} \% 10.84$ \\
\hline
\end{tabular}
$205^{\circ}-206^{\circ}$ にして酸に溶解しアルカリによりて再び析出す.

分析の結果及び分子量測定の結果は略 8,8'-Dichinolyl に一致す.

分 析

（但し $50 \%$ の可性加里艻用ひて測定す） 
分子量测定 (ラスト氏法)

物質 $0.0110 \mathrm{~g}$

融繁隆下 $26^{\circ}$

$\mathrm{C}_{18} \mathrm{H}_{12} \mathrm{~N}_{2}$ としての理論數

樟腀(融點 $\left.176^{\circ}\right) \quad 0.0694 \mathrm{~g}$

分于量 244

256

終りに臨み御懇篤なる御指導を賜はりし恩師近藤致授並びに 的労の便宜を與へ られたる校長村山博士に謹で哚謝し及助力せられたる憍本勝君に謝意を表す。

（昭和 3 年 10 月 24 日 熊本菜學專門學校に於て）

\section{Sonn 氏のフロロアセトフエノン- モノメチールエーテルの樥造 端に服部氏の Kikokunetin に就て}

篠田淳 三

J. Shinoda: Ueber die Konstitution von Phloroacetophenonmono-methyläther u. über Kikokunetin von Hattori.

Sonn 氏は [Ber. 53, 1691, (1925)]二種のフロロアセトフェノンモノメチール エーテルを得其一つの Smp. 觉 $136^{\circ}-137^{\circ}$ 他の Smp. を $205^{\circ}-207^{\circ}$ となせり最 近同氏は [Ber. 2300, (1928)] "Uber die Phloroacetophenon-monomethyläther u. das Vermeintliche Oxy-päonol"と題して此兩者の構造をそれぞれ次の如く決定 せり.<smiles>COC(=O)C1CCOCC1O</smiles>

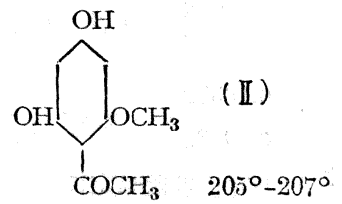

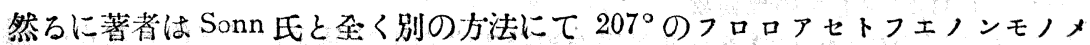

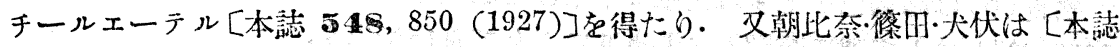
550, 1007, (1927)]泣に Abst. Vol. 22 No. 16, 2946, 2917, (1928)] 139 $-149^{\circ}$ のフロロアセトフエノンモノメチールェーテル觉得たり此の兩者は Sonn 氏の得 たるものと同一なり：著者は兩者のメトオキシの位置学確定すべく Robinson u Venkataraman [Soc. 2344(1926)] の方法に從ひ 207’のフロロア七トフエノン モノメチールエーテルを使用してルテオリントリメチールェーテル Smp. $285^{\circ}$ - 